\title{
Rhinocerotidae from the early Miocene of the Negev (Israel) and implications for the dispersal of early Neogene rhinoceroses
}

\author{
Luca Pandolfi, ${ }^{1 *}$ @ $\odot$ Ran Calvo, ${ }^{2}$ Ari Grossman, ${ }^{3,4,5}$ and Rivka Rabinovich ${ }^{6}$ \\ ${ }^{1}$ Dipartimento di Scienze Della Terra, Università degli Studi di Firenze, Via G. La Pira, 4, 50121, Firenze, Italy <luca.pandolfi@unifi.it> \\ ${ }^{2}$ Geological Survey of Israel, Jerusalem, Israel <rani.calvo@gsi.gov.il> \\ ${ }^{3}$ Department of Anatomy, College of Graduate Studies, Midwestern University, Glendale, Arizona 85308, U.S.A. \\ ${ }^{4}$ College of Veterinary Medicine, Midwestern University, Glendale, Arizona 85308, U.S.A. \\ ${ }^{5}$ Arizona College of Osteopathic Medicine, Midwestern University, Glendale, Arizona 85308, U.S.A <agross@ midwestern.edu> \\ ${ }^{6}$ National Natural History Collections, Institute of Earth Sciences, Institute of Archaeology, The Hebrew University of Jerusalem, Berman \\ Building, Edmond J. Safra Campus, Givat Ram, Jerusalem, 91904, Israel <rivkar@mail.huji.ac.il>
}

\begin{abstract}
A revision of the rhinocerotid material from the Negev (Israel), dating back to the early Miocene (MN3 in the European Mammal Biochronology), highlights the presence of Brachypotherium and a taxon close to Gaindatherium in the Levantine corridor. A juvenile mandible, investigated using CT scanning, displays morphologically distinct characters consistent with Brachypotherium cf. B. snowi rather than with other Eurasian representatives of this genus. Some postcranial remains from the Negev, such as a humerus, display features that distinguish it among Miocene taxa. We attribute these postcrania to cf. Gaindatherium sp., a taxon never recorded outside the Siwaliks until now. This taxon dispersed into the Levantine region during the late early Miocene, following a pattern similar to other South Asian taxa. Brachypotherium cf. B. snowi probably occurred in the Levantine region and then in North Africa during the early Miocene because its remains are known from slightly younger localities such as Moghara (Egypt) and Jebel Zelten (Libya). The occurrence cf. Gaindatherium sp. represents a previously unrecorded range expansion out of Southeast Asia. These new records demonstrate the paleogeographic importance of the Levantine region showcasing the complex role of the Levantine corridor in intercontinental dispersals between Asia and Europe as well as Eurasia and Africa.
\end{abstract}

\section{Introduction}

A diverse early Miocene fauna (Mammal Neogene Zone $3=\mathrm{MN} 3$ ) was reported from the Negev district of Israel during the 1960s to 1980s (Neev, 1960; Savage and Tchernov, 1968; Goldsmith et al., 1982, 1988; Tchernov et al., 1987). The fossil assemblages collected in the Negev Desert (Fig. 1) represent an important record for the paleobiogeography and evolution of early Neogene mammals occupying the area located in the Levantine corridor, between Africa and Eurasia (Tchernov et al., 1987; López-Antoñanzas et al., 2016; Grossman et al., 2019).

In recent years, a new project was launched in which new Miocene localities were found and the older collected fauna was revised (López-Antoñanzas et al., 2016; Grossman et al., 2019). The current contribution includes both elements that were published previously (Tchernov et al., 1987, p. 295-296) and new elements found during the faunal revision.

The reconstructed geological setting is based on a terrestrial fluviatile and lacustrine sedimentary unit, the Hazeva Formation (Calvo and Bartov, 2001), which was deposited during the early to middle Miocene (Zilberman and Calvo, 2013; Bar and Zilberman, 2016). This formation is preserved in the Negev

*Corresponding author mainly in synclinal basins and in cut-and-fill channels, while in the Arava and the Central Negev, it is exposed mainly in tectonically subsided blocks (Fig. 1). Large drainage systems flowed from inland areas in the southeast, toward the Neo-Tethys shoreline, which was located during the early to middle Miocene in today's Be'er Sheva area (Fig. 1.1) (Gvirtzman and Buchbinder, 1969). Estuarine oyster reefs are found within the Hazeva Formation in the Yeroham-Dimona basin (e.g., the Mamshit site; Margaritz, 1972; Goldsmith et al., 1988), attesting to occasional marine transgressions. The Hazeva Formation consists mostly of fluvial, fine- to coarse-grained sandstones, shale, and conglomerates, with some lacustrine marls and limestone (Calvo and Bartov, 2001). It is stratigraphically subdivided into six members (Shahaq, Mashaq, Gidron, Zefa, Rotem, and Hufeira), but also could be subdivided into three litho-tectonic units (Calvo and Bartov, 2001). The upper litho-tectonic unit ("the syntectonic unit") consists of the Rotem and the Hufeira members. The Rotem Member contains low- and high-energy alluvial facies represented by cycles of conglomerate, sand, silt, and clay. The differences between the lithological units of the Rotem and Hufeira members are clearly seen in Figure 1.3. The Oron junction site (OR) is located within the red sandstone and shales at the base of the Rotem Member. The Anthracothere Hill site (AH) is located within the coarse-grained white sandstones at the top of the Rotem Member, just below the Hufeira 


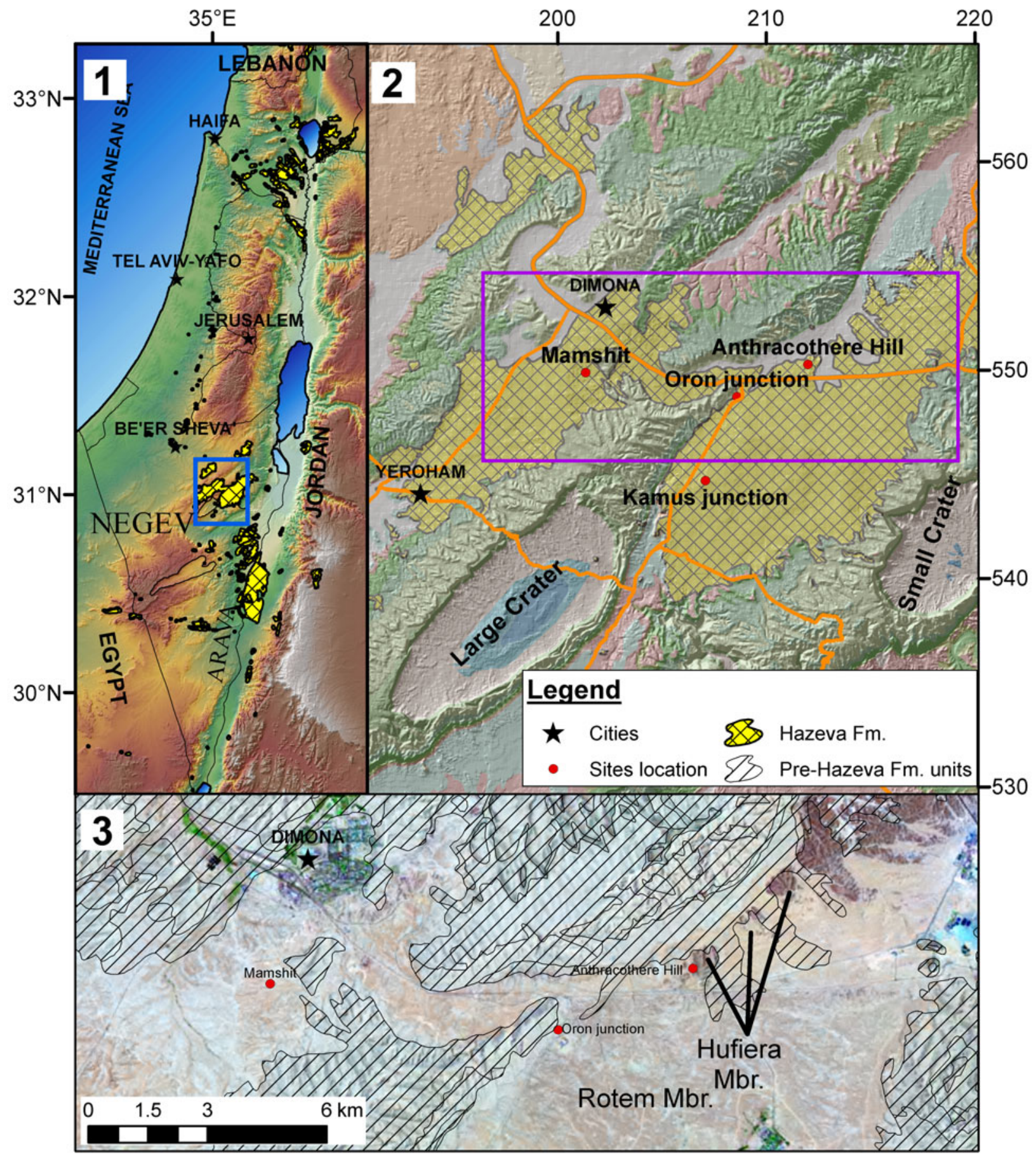

Figure 1. Location and geological map of Miocene deposits in Israel. (1) Location map of all Miocene outcrops in Israel and adjacent countries: the two largest southern exposures of the Hazeva Formation are along the Arava Rift Valley and in the northern Negev, the elevation model (DEM) is based on Hall (1997); geological mapping is based on Sneh et al. (1998); (2) geological map of the synclinal basins and cut-and-fill exposures of the Hazeva Formation in the northern Negev; site localities: Oron junction (OR), Anthracothere Hill (AH), Kamus junction (KJ), and Mamshit; coordinate system: Israel Transversal Mercator projection; (3) Hazeva Formation members emphasized in a Landsat image: red-colored sandstones and clays of the Rotem Member against the dark conglomerate of the Hufiera Member.

Member. Recently, rodents and anthracothere remains were reported from the $\mathrm{AH}$ site and the Kamus junction site (KJ), respectively (López-Antoñanzas et al., 2016; Grossman et al., 2019). Those sites are located along one of the main drainage systems that crossed the elevated anticlines within cut-and-fill channels. Two of them are clearly seen in Figures 1.2 and 1.3.
Based on the geomorphological relationships between episodes of marine invasion and terrestrial erosion in the Be'er Sheva area, Bar and Zilberman (2016) concluded that deposition of the Hazeva Formation ended before ca. 16-14 Ma.

The fauna from the Negev comprises a mix of taxa with an African origin (e.g., Prodeinotherium, Gomphotherium) and 
taxa with an Eurasian origin (e.g., Eotragus, Listriodon, Dorcatherium) (Tchernov et al., 1987; Grossman et al., 2019). Further, the age of the fauna corresponds with the beginning of the Orleanian Land Mammal Age and the African-Eurasian faunal interchanges of the first dispersal linked to the Proboscidean Datum Event, with the renewal of Agenian faunas and the extinction of the last Oligocene taxa in Europe (Tassy, 1990; Gentry et al., 1999; Made, 1999; Koufos et al., 2003; Antoine and Becker, 2013; Scherler et al., 2013; Sen, 2013).

Despite its undisputable importance, the fossil fauna from the Negev has hardly been investigated or revised since the work of Tchernov et al. (1987). Recently, a new project was launched to revise the old collections (López-Antoñanzas et al., 2016), and survey and excavate new localities. Since then, new rodent taxa were recognized in the old collections (López-Antoñanzas et al., 2016) and new species, such as the anthracotheriid Sivameryx, were described from new collections (Grossman et al., 2019), highlighting the role of the corridor in intercontinental faunal dispersals and the need for the work underway.

As part of this effort, we describe here and revise the rhinocerotid material collected from the Rotem and Yeroham basins in the Negev of Israel (Fig. 1.3). This revision includes an update of the systematic attribution of the studied material and suggests a new framework for the paleobiogeography and dispersal of Rhinocerotina between and within Africa and Eurasia during the early Neogene.

Localities assigned to the Paleogene-Neogene transition and the Miocene are poorly documented in the Levantine Corridor and neighboring areas, with only a few of these yielding remains of Rhinocerotidae. In northern Africa, brachypotheres have been reported from the early Miocene sites of Jebel Zelten (Libya) and Moghara (Egypt) (Fourtau, 1920; Hamilton, 1973; Hamilton et al., 1978; Geraads, 2010). In Saudi Arabia, Rhinocerotidae are recorded from the early middle Miocene (MN5) Dam Formation at Ad Dabtiyah, which yielded remains of an indeterminate species of "dicerorhine" (i.e., two-horned rhinocerotine) and of a brachypothere (Gentry, 1987), and at Al-Sarrar, which yielded remains of an indeterminate species of acerathere and scanty remains of an indeterminate species of a dicerorhine (Thomas et al., 1982). Several early Neogene Rhinocerotidae taxa are reported from areas farther away from the Levantine Corridor.

In Western Europe, early Neogene rhinocerotids are represented by five genera and seven species belonging to the Rhinocerotinae that are endemic to different geographic areas (Antoine et al., 2000; Antoine and Becker, 2013). The records of Rhinocerotinae incertae sedis (usually called aceratheres sensu lato) and Teleoceratina extend at least to the early Miocene (some genera since the Oligocene), whereas Rhinocerotina occur for the first time in Europe during the late early Miocene with Lartetotherium (MN4) (Guérin, 1980; Heissig, 2012). The record from South Asia includes numerous genera and species from various sites (i.e., Chitarwata Formation, Bugti Hills, Pakistan; Métais et al., 2009; Antoine et al., 2010). This region is characterized by the occurrence of several taxa such as the aceratheres s.l. (Pleuroceros, Mesaceratherium, Plesiaceratherium, Protaceratherium), and by the presence of teleoceratines (Brachypotherium and Prosantorhinus) (Métais et al., 2009; Antoine et al., 2010; Antoine, in press). In addition, some endemic taxa, such as the elasmotheriine Bugtirhinus praecursor Antoine and Welcomme, 2000, and the rhinocerotinans Gaindatherium cf. G. browni Colbert, 1934, and cf. Rhinoceros, are also documented in South Asia (Métais et al., 2009; Antoine et al., 2010; Antoine, in press). Recently, Pleuroceros, Protaceratherium, and Bugtirhinus were also identified in lower Miocene deposits of Southeast Asia (ca. MN3, Thailand; Prieto et al., 2018). In Africa, the record of Rhinocerotidae extends to ca. $20 \mathrm{Ma}$, comprising endemic taxa, such as the large rhinocerotinans Rusingaceros leakeyi (Hooijer, 1966) and "Diceros" australis Guérin, 2000, the elasmotheriines Chilotheridium pattersoni Hooijer, 1971, Turkanatherium acutirostratum Deraniyagala, 1951, and Ougandatherium napakense Guérin and Pickford, 2003 (Geraads, 2010; Geraads et al., 2016), and the teleoceratines Brachypotherium snowi Fourtau, 1920 and B. minor Geraads and Miller, 2013 (Geraads and Miller, 2013; Grossman et al., 2014). Despite this rich record, less is known of Rhinocerotina (taxa most-closely related to the extant rhinoceroses), including their species distribution and their origin compared to other groups of the family Rhinocerotidae.

\section{Materials and methods}

The fragile rhinocerotid remains from the Negev are curated and housed at the National Natural History Collections of The Hebrew University of Jerusalem (Israel). We base the comparisons on direct observations of the fossils, as well as published material on early and early middle Miocene rhinocerotids. We base our comparisons on the characters codified by Antoine et al. $(2003,2010)$ for several early Neogene rhinocerotids, such as Pleuroceros, Diaceratherium, Brachypotherium, Protaceratherium, Prosantorhinus, Lartetotherium, Plesiaceratherium, Mesaceratherium, and Bugtirhinus. Among published works, we consulted: Hooijer (1966) for Rusingaceros and Turkanatherium; Heissig (1972) for Rhinocerotini indet. = Gaindatherium sp.; Cerdeño (1986, 1992, 1996a) for Lartetotherium; Cerdeño (1993) for Brachypotherium and Diaceratherium; Cerdeño (1996b) for Prosantorhinus; Santafé-Llopis et al. (1987) for "Dicerorhinus montesi" Santafé-Llopis, Casanovas-Cladellas, and Belinchon, 1987 = Lartetotherium montesi in Cerdeño and Nieto (1995); Antoine (1997, 2002) for Hispanotherium beonense (Antoine, 1997); Guérin (2003) for "Diceros" australis and Chilotheridium pattersoni; Antoine et al. (2010) for Pleuroceros blanfordi Antoine et al., 2010 and Mesaceratherium welcommi Antoine et al., 2010; Heissig (2012) for Lartetotherium and Hoploaceratherium; and Becker and Tissier (2020) for Hispanotherium, Plesiaceratherium, and Lartetotherium. We made direct observations on juvenile mandibles and teeth and postcranial remains of Brachypotherium and Hoploaceratherium from the Czujan sandpit (Czech Republic; Březina et al., 2017; MMB), of Rhinocerotinae indet. from the Dam Formation at Ad Dabtiyah (Saudi Arabia; Gentry, 1987; NHMUK), Diaceratherium from Chilleurs-aux-Bois (France; NHMUK), Hoploaceratherium and Lartetotherium from Sansan (France; NHMUK, NMB) and several Spanish localities (MNCN), Protaceratherium minutum (Cuvier, 1822) from the Paris Basin (France; MGGC), and Bugtirhinus from the Bugti Hills (Pakistan; NHMUK). Classification above genus level follows Antoine et al. (2010). Description of postcranial remains is based on Guérin (1980) and Antoine (2002). We measured the studied specimens 
using a digital caliper. Measurements and comparative tables are in Supplementary Data 1.

Repositories and institutional abbreviations.-HUJI, National Natural History Collections of The Hebrew University of Jerusalem, Jerusalem (Israel); MGGC, Museo Geologico Giovanni Capellini, Bologna (Italy); MMB, Moravian Museum, Brno (Czech Republic); MNCN, Museo National de Ciencias Naturales, Madrid (ES); NHMUK, The Natural History Museum, London (UK); NMB, Naturhistorisches Museum, Basel (Switzerland).

Anatomical and morphometrical abbreviations.-APD, antero-posterior (mesio-distal) diameter; C6, sixth cervical vertebra; DAPD, distal antero-posterior diameter; DTD, distal transversal diameter; DTPA, proximal transverse diameter of the articular surface; $\mathrm{M} / \mathrm{m}$, upper/lower molar; max, maximal; min, minimal; mt, metatarsal; $\mathrm{P} / \mathrm{p}$, upper/lower premolar.

\section{Systematic paleontology}

Order Perissodactyla Owen, 1848

Superfamily Rhinocerotoidea Gray, 1825

Family Rhinocerotidae Gray, 1821

Subfamily Rhinocerotinae Gray, 1821

Tribe Rhinocerotini Gray, 1821

Subtribe Teleoceratina Hay, 1902

Genus Brachypotherium Roger, 1904

Type species.—Brachypotherium brachypus (Lartet, 1837).

Brachypotherium cf. B. snowi Fourtau, 1920

Figures 2, 3, Supplementary Data 1, 2

Description.-AH 1458 includes part of the left horizontal ramus, including the unerupted $\mathrm{p} 2$, erupting $\mathrm{p} 3$, and the roots of $\mathrm{dp} 3$ and a part of dp4 (Fig. 2.1). The fragment extends mesially, terminating past the large mental foramen that is easily discerned in buccal view (Fig. 2.2) below the anterior portion of dp3. In lingual view (Fig. 2.3), due to the state of preservation of the specimen, it is difficult to ascertain the morphology of the lingual groove of the mandible. An erupting p3 (L $\max =\sim 40 \mathrm{~mm}$ ) and a premolar bell of p2 (L $\max =\sim 27.5 \mathrm{~mm} ; \mathrm{TD}=\sim 14.5 \mathrm{~mm})$ are evident inside the mandible (Fig. 2; Supplementary Data 2,3). The lingual valleys of the two teeth are V-shaped, and the lingual and labial cingula are absent (Supplementary Data 2,3). On p2 (Fig. 3), the anterior lingual valley is absent, the paralophid is long and simple, and the paraconid is developed. On p3 (Fig. 3), there is a distal cingulum, the lingual groove is marked and reaches the base of the crown, the paralophid is straight and does not reach the lingual rim of the tooth, and the metaconid and entoconid are not constricted.

Materials._A partial left hemimandible of a juvenile individual, AH 1458.

Remarks.-Bugtirhinus differs from AH 1458 by its more hypsodont teeth and much smaller size (see Antoine et al.,
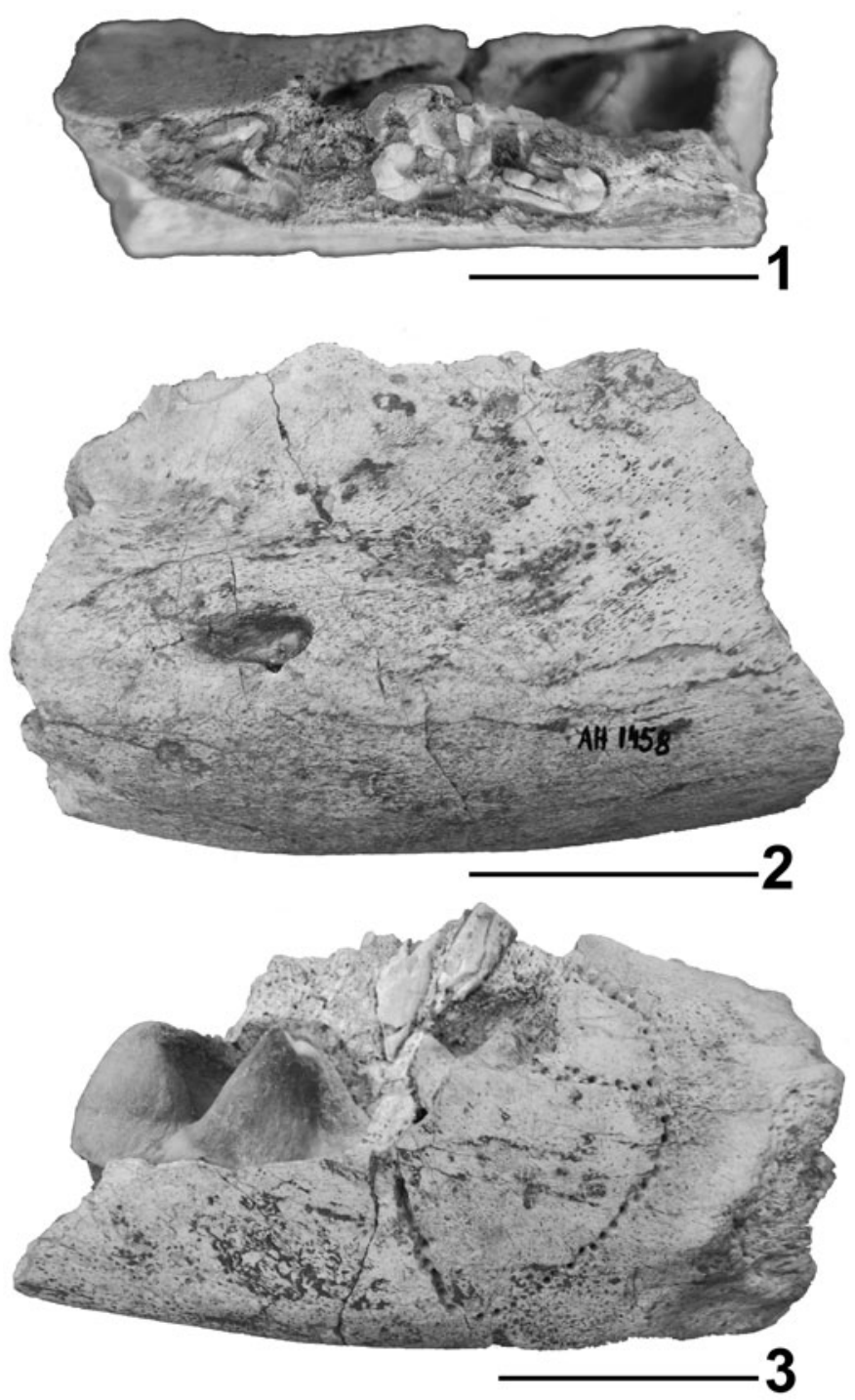

Figure 2. Brachypotherium cf. B. snowi left hemimandible HUJI AH 1458 from the Negev, Israel. (1-3) Occlusal, buccal, and lingual views. Scale bars = $5 \mathrm{~cm}$.

2010). Turkanatherium acutirostratum has proportionally shorter and wider p3 and narrower lingual valleys (Hooijer, 1966, pl. 9, fig. 4). Aceratheres have narrower lingual valleys. Contrary to Chilotheridium from Loperot, the labial groove on the p3 of AH 1458 is shallower (cf., Hooijer, 1971). Rhinocerotines differ from AH 1458 by a curved and lingually flexed paralophid of the p3. A juvenile mandible of Lartetotherium from Relea (middle Miocene, Spain: MNCN NM18102) differs from the studied specimen by its U-shaped lingual valleys and postero-lingually bent paralophids on the p3. Lower teeth of G. browni described by Heissig (1972) from Nagri have narrower lingual valleys; in addition, in $G$. browni, the lingual groove of the $\mathrm{p} 3$ does not reach the base of the crown and the paralophid is curved. In "Aprotodon" fatehjangense (Pilgrim, 1910) the labial groove of $\mathrm{p} 3$ does not reach the base of the crown, labial and lingual cingula are present, and the paralophid on p2 is curved (Heissig, 1972; Antoine et al., 2003). In B. brachypus the paraconid on $\mathrm{p} 2$ is 

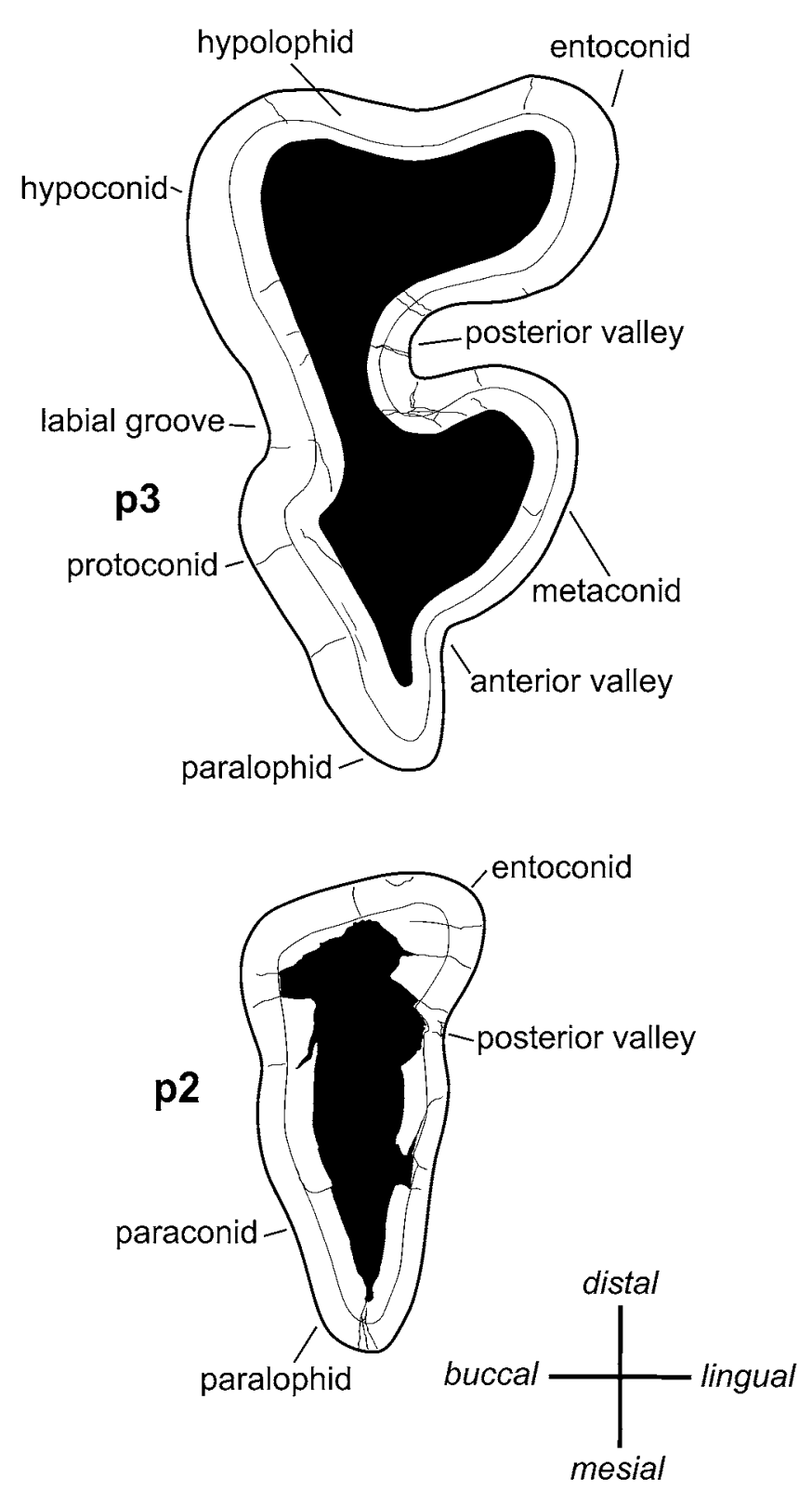

Figure 3. Brachypotherium cf. B. snowi left hemimandible (reversed) HUJI AH 1458 from the Negev, Israel; p2 (length $\sim 27.5 \mathrm{~mm}$ ) and p3 (length $\sim 40$ $\mathrm{mm}$ ) drawings from CT slides (Supplemental Figure S1).

reduced, the labial cingulum on the premolars is reduced and the metaconid is constricted; in general, the teeth are shorter and wider than on the Negev specimens. In $B$. perimense (Falconer and Cautley, 1846) the lingual groove of p3 is smooth and does not reach the base of the crown, the lingual valleys are U-shaped whereas the paraconid is reduced (Heissig, 1972; Antoine et al., 2021). In B. minor, the paralophid of $\mathrm{p} 3$ is short and curved and the paraconid reduced (Geraads and Miller, 2013). In B. snowi from Jebel Zelten and Moghara (LP, personal observation at NHMUK, 2013; Fourtau, 1920; Hamilton, 1973), similar to AH1458, the p2 is long and narrow $(\mathrm{L} \max =27 \mathrm{~mm} ; \mathrm{TD}=17 \mathrm{~mm}$; Hamilton, 1973), the p3 has a marked labial groove that extends to the base of the crown, the hypolophid and metalophid are well developed, and the paralophid is straight (not flexed lingually).

\section{Subtribe Rhinocerotina Gray, 1821 Rhinocerotina indet.}

Description.-The tooth fragment (OR 1008) displays rough enamel and is a fragment of the protocone of an upper molar. The cone is enlarged at the base (APD $=\sim 1.7 \mathrm{~mm}$ ) and the mesial cingulum is partially preserved. A weak cingulum is present on the distal side of the cone (the entrance of the median valley), similar in height to the mesial cingulum.

The vertebra C6 (AH 2068) is missing the right transverse process and the spinous process (Fig. 4.1). In anterior view (Fig. 4.1), the left transverse process is well developed and massive, with evident (but badly preserved) dorsal (laterally directed) and ventral (ventrally directed) tubercles. The process is perforated by an elliptical transverse foramen, with its major axis oblique with respect to the major dorsal-ventral axis of the bone. The anterior articular head of the vertebral body is elliptical, with the main axis parallel to that of the bone; its ventral border is convex. The posterior articular surface of the vertebral body is subcircular (Fig. 4.2), wider than the anterior one, and slightly concave. The angle between the dorsal side of the transverse process and the ventral side of the vertebral arch is $<90^{\circ}$. The anterior articular processes are directed upward and the angle with the spinous process is very sharp. The vertebral canal is taller than it is wide, with a concave ventral border and a very sharp dorsal border. In anterior view, the anterior articular surface of the vertebral body is squarer, particularly its dorsal part. In lateral view, the anterior dorsal process is less extended anteriorly than the articular surface, whereas the posterior dorsal process is slightly more posteriorly extended than the posterior articular surface. The anterior articular surface of the vertebral body is more dorsally placed on the vertebral body with respect to the posterior one.

Materials.-A fragment of a right protocone of an upper tooth (misidentified as P1 in Tchernov et al., 1987), OR 1008; a fragmentary cervical vertebra (sixth), AH 2068.

Remarks. - It is very difficult to assign a fragment of a tooth to a well-defined genus or species. Nevertheless, a comparison with several upper teeth of early Miocene Rhinocerotidae enables several considerations. (1) A mesial cingulum and a weak cingulum at the entrance of the median valley of OR 1008 resembles the protocone of an M3 from Rusinga (NHMUK M32951); also, as in OR 1008, the protocone on NHMUK M32951 is antero-posteriorly enlarged; an M1 from Rusinga (NHMUK M32946) exhibits a protocone with similar characteristics as well. (2) The protocones of the upper molars of Brachypotherium brachypus from Villefranche d'Astarac (NHMUK 33522) have a continuous lingual cingulum and lack the weak cingulum along their distal side. (3) The protocones of isolated M2 (NHMUK M29269) and M3 (NHMUK M29254) from Jebel Zelten, assigned to Brachypotherium snowi, have a flattened lingual side and show no trace of a cingulum on the distal side. (4) The molars of Bugtirhinus praecursor from the early Miocene of Bugti 

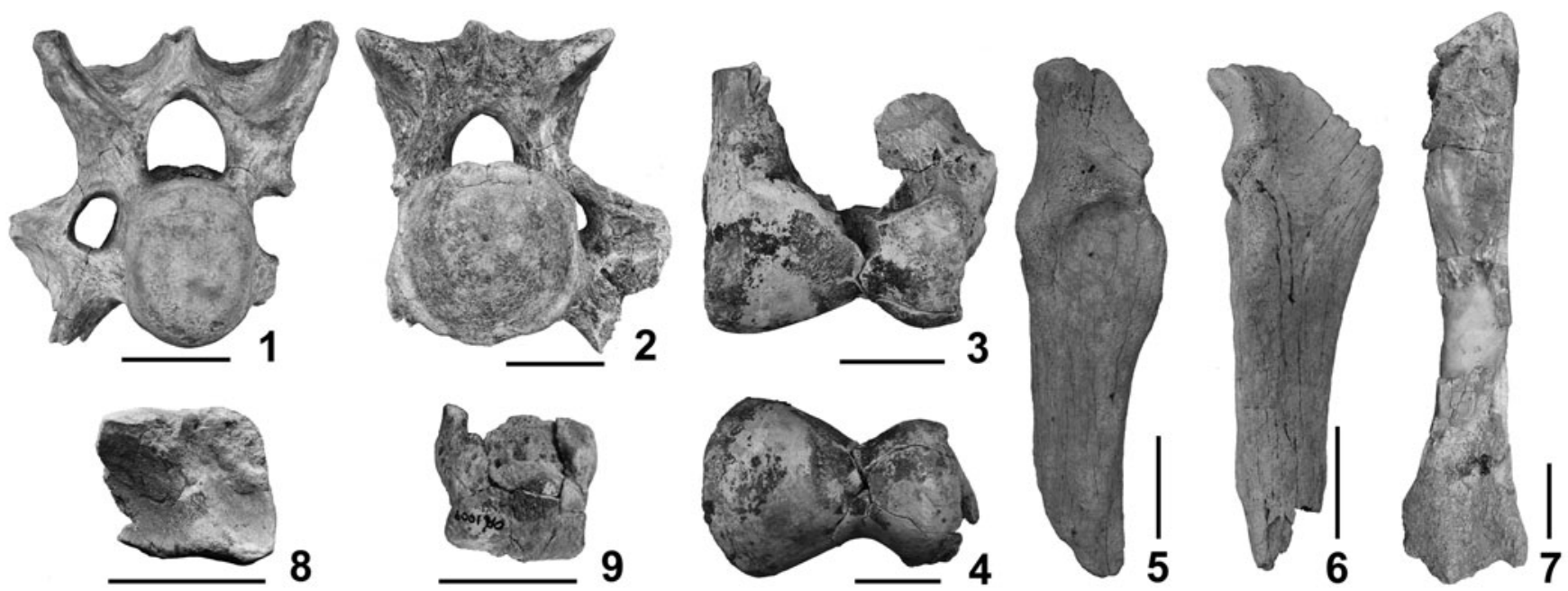

Figure 4. Rhinocerotidae remains from the Negev, Israel. (1, 2) HUJI AH 2068, sixth cervical vertebra, anterior and posterior views; (3, 4) HUJI OR 1046, distal humerus, anterior and distal views; $(\mathbf{5 , 6})$ HUJI OR 1044, ulna, anterior and lateral views; (7, 8) HUJI OR 1043, tibia, anterior and distal views; (9) HUJI OR 1009, distal mtIII, anterior view. Scale bars $=5 \mathrm{~cm}$.

Hills have a narrower protocone (NHMUK; Antoine and Welcomme, 2000), and are more flattened on the lingual side; the same is true for Prosantorhinus molars from Sandelzhausen (Cerdeño, 1996b) as well. (5) The protocone of a M3 from Ad Dabtiyah (NHMUK 36897), identified as ?Dicerorhinus sp. aff. D. sansaniensis (Lartet, 1851), resembles OR 1008 because it is inflated and has a mesial cingulum, but differs from the Negev specimen because it lacks the weak cingulum on the distal side.

Thus, pending discovery of more dental material from the early Miocene of Israel and considering the similarities with the material from Rusinga and Ad Dabtiyah, we tentatively refer OR 1008 to Rhinocerotina indet.

Very few cervical vertebrae of Miocene Rhinocerotidae have been published, and thus we can only remark that the size of the sixth cervical vertebra from the Negev (AH 2068) resembles that of Lartetotherium from Sansan and is somewhat larger than that of Hoploaceratherium (Supplementary Data 1, Supplementary Table S1). The neural canal in AH 2068 is proportionally narrower and higher than in Teleoceras (cf., Short et al., 2019); the anterior articular processes are more upwardly directed than in Teleoceras and resemble those of Stephanorhinus (Made, 2010, pl. 10). The specimen from the Negev is here tentatively assigned to Rhinocerotina.

Genus Gaindatherium Colbert, 1934

Type species.—Gaindatherium browni Colbert, 1934.

\section{cf. Gaindatherium sp.}

Figures 4, 5

Description.-As previously mentioned, the elements are poorly preserved; however, we identified important characteristics permitting detailed comparisons and identification.

OR 1046 is a distal portion of a left humerus preserving the distal diaphysis and epiphysis. The medial epicondyle is evident in anterior view (Figs. 4.1, 5.1), the medial border of the medial lip of the articular condyle is oblique, whereas the lateral border of the lateral lip is almost straight. The trochlea is asymmetric, the medial lip is more developed and wider than the lateral lip, and the trochlear gorge is deep. The partially preserved coronoid fossa appears well marked and deep; the radial fossa is well marked. The epicondylar crest is weak and the lateral border of the distal epiphysis is oblique. In posterior view, the olecranon fossa is partially preserved, and wider than it is high; the lateral epicondyle is not preserved and the epitrochlea is partially damaged. In medial view, the articular border of the trochlea is smoothly rounded and ends weakly in the proximal-anterior side at the level of the condylar fossa. In distal view (Fig. 4.2), the medial lip of the trochlea is clearly much more developed and wider than the lateral lip.

OR 1044 is a right ulna missing the distal epiphysis and proximal portion of the olecranon process (Fig. 4.5). The olecranon and the diaphysis are aligned (Fig. 4.6) and the proximal articular facets for articulation with the radial head are fused to the shaft of the ulna on both sides. The articular surfaces for the humerus are asymmetric; the medial surface is more elongated proximodistally than the lateral one. The latter is wider and less concave than the medial surface. The diaphysis has a subtriangular section (Fig. 4). The articular facet of the humerus is worn.

The tibia (OR 1043) is badly preserved. The proximal epiphysis is strongly damaged, but the tibial spine is partially preserved, thus it is possible to estimate the maximal length of the bone $(\sim 334 \mathrm{~mm})$. The diaphysis was reconstructed because it was severely damaged (Fig. 4.7); no synostosis appears along the diaphysis. The distal epiphysis is much better preserved than other parts of the bone (Fig. 4.8). The mediodistal gutter is absent. In distal view, the distal articular surface is wider than deep and is less developed than the distal epiphysis. The distallateral articular surface is oblique with respect to the anterior border of the distal epiphysis; it is narrower and slightly longer than the distal-medial articular surface (Fig. 4.8). The latter is partially damaged on the medial side and is separated from the lateral surface by an antero-posteriorly concave and 

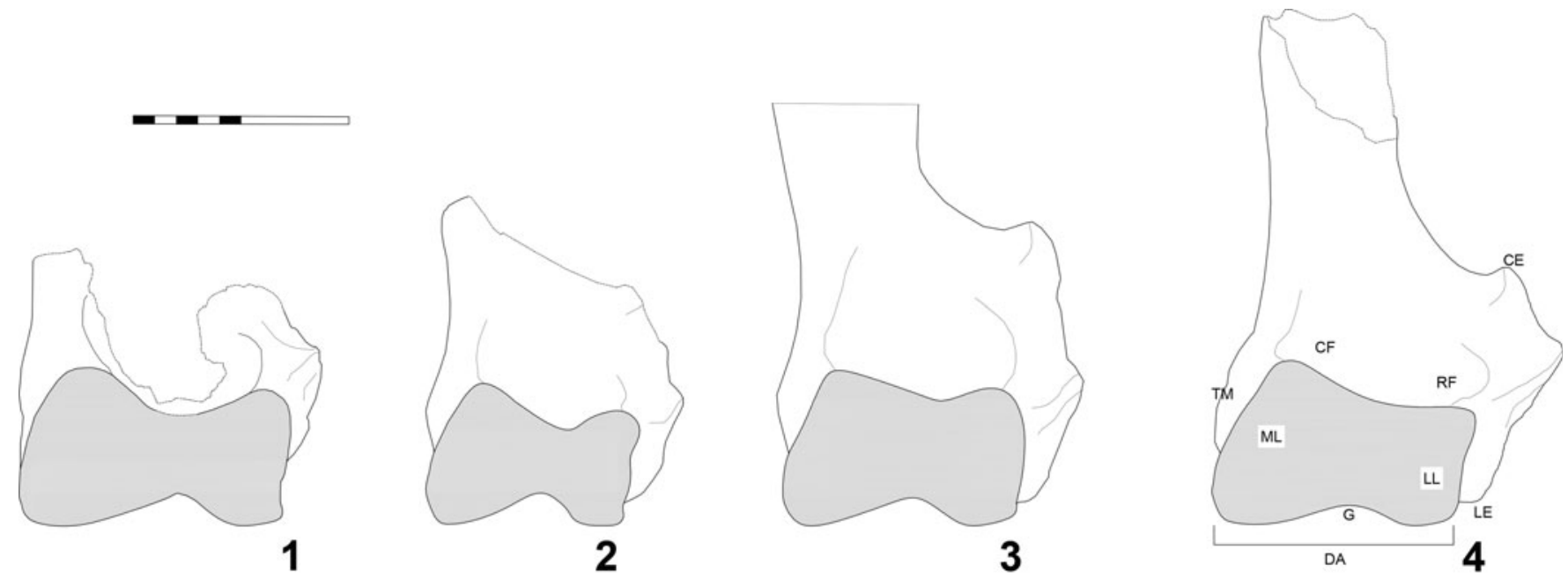

Figure 5. Morphological comparison between the distal humerus from the Negev, Israel, and humeri of selected early Miocene rhinocerotids, in anterior view. (1) HUJI OR 1046, cf. Gaindatherium sp. from the Negev, Israel; (2) MGGC 7224, Protaceratherium minutum from the Paris basin; (3) NHMUK M27456, Hoploaceratherium tetradactylum from Sansan; (4) MMB no collection number, Brachypotherium brachypus from the Czujan sandpit. Abbreviations: CE = epicondylar crest; $\mathrm{CF}=$ coronoid fossa; $\mathrm{DA}=$ distal articular surface (trochlea); $\mathrm{G}=$ trochlear notch; $\mathrm{LE}=$ lateral epicondyle; $\mathrm{LL}=$ lateral lip of the trochlea; $\mathrm{ML}=$ medial lip of the trochlea; $\mathrm{RF}=$ radial fossa; $\mathrm{TM}=$ tuberosity on the medial face. $\mathrm{Scale} \mathrm{bar}=10 \mathrm{~cm}$.

transversally convex saddle. The anterior border of the distal epiphysis is sinuous in distal view.

The third metatarsal (OR 1009) displays a smooth and low intermediate relief, and the distal articular surface is transversally smaller than the distal epiphysis (Fig. 4.9). The anteroproximal border of the distal articulation is rounded.

Materials.-A portion of a distal left humerus (Tchernov et al., 1987), OR 1046; a right ulna missing the distal epiphysis and the proximal part of the olecranon (Tchernov et al., 1987), OR 1044; a left tibia with an extremely damaged proximal epiphysis and diaphysis, OR 1043; a left distal third metatarsal (Tchernov et al., 1987), OR 1009.

Remarks.-With respect to the studied specimen, in Protaceratherium minutum the medial tuberosity of the humerus is more prominent and placed lower on the medial face, the trochlear gorge is narrower and deeper in anterior view, and the epicondylar crest is well developed (Fig. 5.2). Unlike the humerus from the Negev, in the humerus of Pleuroceros blanfordi the olecranon fossa is high, there is a scar on the trochlea, and a distal gutter on the epicondyle is present (Antoine et al., 2010). The humeri of Hoploaceratherium tetradactylum (Lartet, 1851) (Fig. 5.3) and Aceratherium incisivum (Cuvier, 1822) are larger than the humerus from Negev, although the available data are too scarce for an exhaustive morphometrical comparison (Supplementary Data 1, Supplementary Table S2). In distal view (Guérin, 1980, fig. 32), the lateral lip of the distal trochlea is narrower than in the studied specimen and the anterior border of the trochlear gorge is wider. Brachypotherium brachypus and Plesiaceratherium mirallesi (Crusafont, Villalta, and Truyols, 1955) display a higher and narrower olecranon fossa with respect to OR 1046 (cf., Antoine et al., 2010). In Brachypotherium, the epicondylar crest is much more developed, as is the lateral epicondyle; the distal trochlea is laterally oriented with an oblique lateral lip (Fig. 5.4).
Prosantorhinus douvillei (Osborn, 1900) and Diaceratherium aurelianense (Nouel, 1866) have a low olecranon fossa (Cerdeño, 1993, pl. 2, fig. 3). In addition, the humerus of Prosantorhinus is smaller than the studied specimen (cf., Cerdeño, 1996b) and has a higher distal epicondyle (Cerdeño, 1996b, pl. 19, fig. 4). In Diaceratherium, the humeral crest and the epicondylar crest are much more prominent than in the studied specimen, the coronoid fossa is weakly marked, and the lateral epicondyle is more proximal and curved externally. Hispanotherium (Aegyrcitherium) beonense has a much more developed lateral non-articular side of the distal epiphysis (e.g., Antoine, 2002, fig. 198b), the epicondylar crest is more marked, and there is a scar on the trochlea (Antoine, 2002, fig. 199). Hispanotherium grimmi Heissig, 1974, displays a wider distal trochlea with a wider distal epiphysis and medial tuberosity, more prominent in anterior view (Heissig, 1976, fig. 3). In medial view, the articular surface stops well before the anterior border of the condylean fossa. The humerus of the middle Miocene Victoriaceros kenyensis Geraads, McCrossin, and Benefit, 2012 (NHMUK M32755; Geraads et al., 2012) is much more massive than the Negev specimen and displays a more developed medial tuberosity on the distal epiphysis. The humerus from the Negev is less massive than that of Rusingaceros leakyei, but a detailed morphological comparison is not possible because the distal epiphysis of the Rusinga humerus is damaged (Hooijer, 1966, pl. 2, fig. 2). Some morphological characters of OR 1046 are shared with Lartetotherium sansaniense from Sansan (Guérin, 1980; Heissig, 2012). In particular, both have a marked crest on the lateral face, lack a central fossa on the medial face, and the coronoid and radial fossae are deep with a well-marked lateral border. Nevertheless, in posterior view, the olecranon fossa of L. sansaniense is narrower than in the specimen from the Negev. "Dicerorhinus montesi" Santafé-Llopis et al., 1987, resembles L. sansaniense in having a higher and narrower olecranon fossa than the Negev specimen. The latter closely resembles the humerus from Nagri reported by Heissig (1972, p. 34) and 


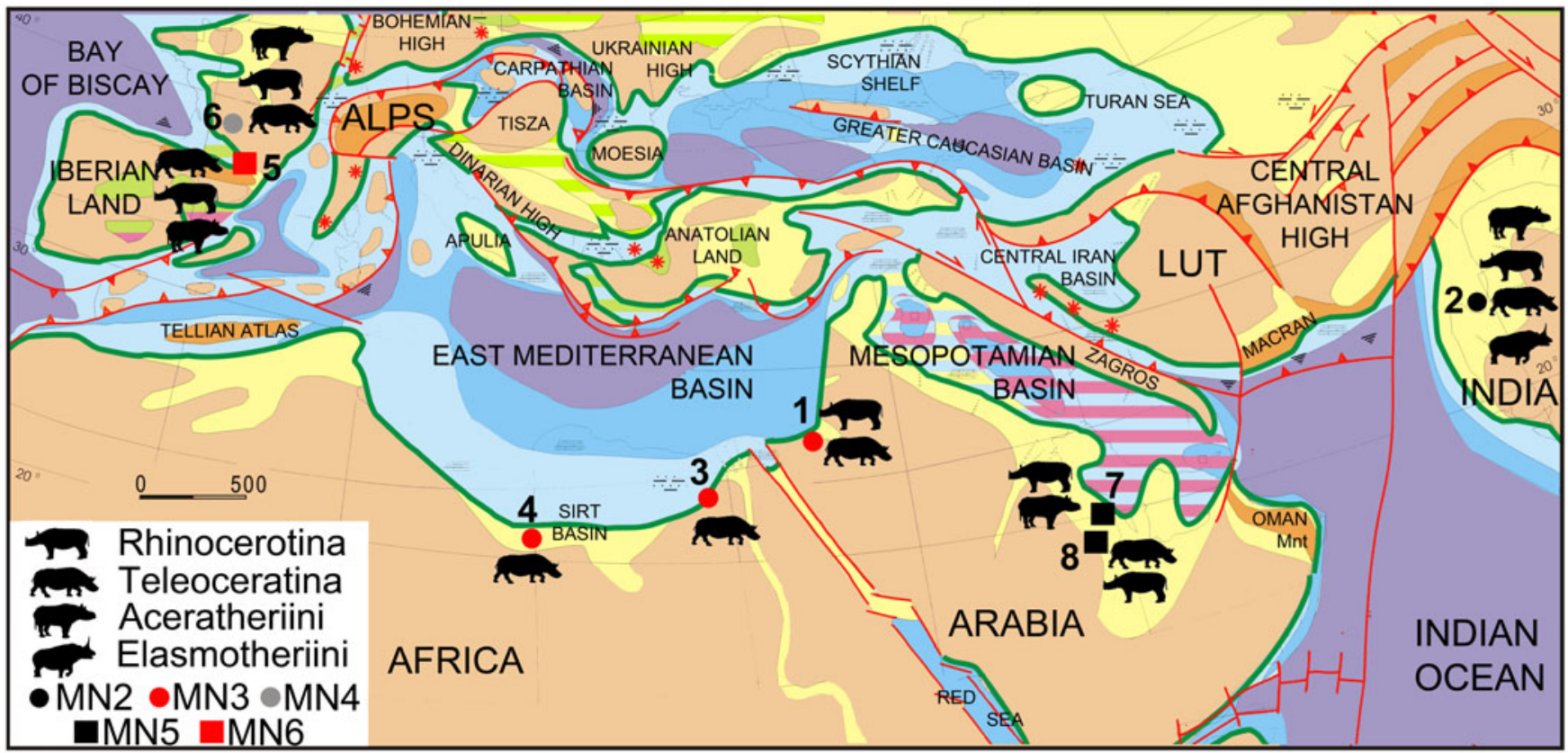

Figure 6. Early Miocene paleogeographic map (modified from Popov et al., 2004) showing selected localities mentioned in the text. (1) The Negev, early Miocene, MN3, Israel; (2) Bugti Hills (Upper Member of Chitarwata Formation), early Miocene, MN2, Pakistan; (3) Moghara, early Miocene, MN3, Egypt; (4) Jebel Zelten, early Miocene, MN3, Libya; (5) Sansan, middle Miocene, MN6, France; (6) Bézian-La Romieu, late early Miocene, MN4, France; (7) Al-Sarrar, middle Miocene, MN5, Saudi Arabia; (8) Ad Dabtiyah, middle Miocene, MN5, Saudi Arabia. The Rhinocerotidae taxa for each locality are listed in Table 1. Mnt = Mountain

assigned to Rhinocerotini. The morphology and proportions of the studied humerus also resemble that assigned to ?Dicerorhinus sp. aff. D. sansaniensis and collected at Ad Dabtiyah (Saudi Arabia) (Gentry, 1987; LP, personal observations at NHMUK, 2013).

The described characters allow the studied ulna (OR 1044) to be distinguished from Plesiaceratherium mirallesi which displays an open angle between the diaphysis and the olecranon (cf., Antoine et al., 2010). The ulna is more slender than those of "Diceros" australis, Brachypotherium, and Diaceratherium (Supplementary Data 1, Supplementary Table S3). The size of the diaphysis (Supplementary Data 1, Supplementary Table S3) resembles the rhinocerotid from Ad Dabtiyah (NHML M36912) and Lartetotherium from Sansan (Heissig, 2012), but with a smaller DTPA ( $\sim 58 \mathrm{~mm}$ in OR 1044, size ranges between $77-$ $90 \mathrm{~mm}$ in Lartetotherium).

The tibia OR 1043 (DAPD $=54.37 \mathrm{~mm}$ ) is close in size to Lartetotherium from the Vallesian of Spain (DAPD size ranges between 55-62.8 mm), but is smaller than the older Lartetotherium from Sansan (DAPD size ranges between 64.5-70 mm) (Supplementary Data 1, Supplementary Table S4). The studied specimen is more slender and proportionally different from "Diceros" australis, Brachypotherium, Diaceratherium, and Plesiaceratherium. The mediodistal gutter is present in Plesiaceratherium and Pleuroceros and absent in Mesaceratherium. In the latter, the anterior border of the distal epiphysis is straight. The general morphology of the distal articular surface resembles the tibia from Ad Dabtiyah (NHML M3678), and both closely resemble the tibia NMB SS124, assigned to Lartetotherium sansaniense. According to Gentry (1987), the tibia from Ad Dabtiyah is close to a tibia from Sansan NHML 27458; nevertheless, the latter displays a different morphology of the distal surface (oblique anterior and posterior borders, transversally narrower articular surfaces, lateral distal tuberosity more developed) and belongs to Hoploaceratherium. The tibia of Gaindatherium is unknown at present.

The smooth and low intermediate relief of the distal articular surface of the third metatarsal (OR 1009) distinguishes the specimen from the Negev from Brachypotherium, Diaceratherium, Pleuroceros, Mesaceratherium, Plesiaceratherium, and Prosantorhinus. OR 1009 shares this character with Lartetotherium and the extant taxa (cf., Antoine, 2002, p. 231; Antoine et al., 2010, p. 194). The specimen from the Negev $(\mathrm{DTD}=45.57 \mathrm{~mm}$; DAPD $=32.15 \mathrm{~mm}$ ) is anteroposteriorly smaller than Diaceratherium (min-max DAPD $=37-50 \mathrm{~mm}$ ), is transversally shorter than Brachypotherium (min-max DTD $=59-70.6 \mathrm{~mm}$ ), Rusingaceros $(\mathrm{DTD}=\sim 60 \mathrm{~mm}$ ), and "D." australis (min-max DTD $=55.5-61.5 \mathrm{~mm}$ ), and is morphometrically close to the third metatarsals of Lartetotherium reported by Cerdeño (1993, min$\max \mathrm{DTD}=43.8-54.5 \mathrm{~mm}$; $\min -\max$ DAPD $=31-39.6 \mathrm{~mm}$ ). OR 1009 is slightly smaller than the Lartetotherium from Sansan (Supplementary Data 1, Supplementary Table S5; min-max $\mathrm{DTD}=47-53.5 \mathrm{~mm}$; min-max DAPD $=34-40.5 \mathrm{~mm}$ ) and differs from it in having less-prominent and less-sharp supra-articular tuberosities (Heissig, 2012, fig. 349). The studied specimen is distinct from Rhinocerotini indet. (= Gaindatherium sp.) from Nagri (Heissig, 1972, pl. 25, figs. 1, 2), but it is very similar to Gaindatherium sp. (mtIII Y46571) from the Siwaliks of Potwar Plateau by having blunt and rounded supra-articular tuberosities and a low articular surface in anterior view.

\section{Discussion}

Rhinocerotids are documented in several areas of Eurasia and Africa during the early Neogene (Antoine et al., 2010; Geraads, 


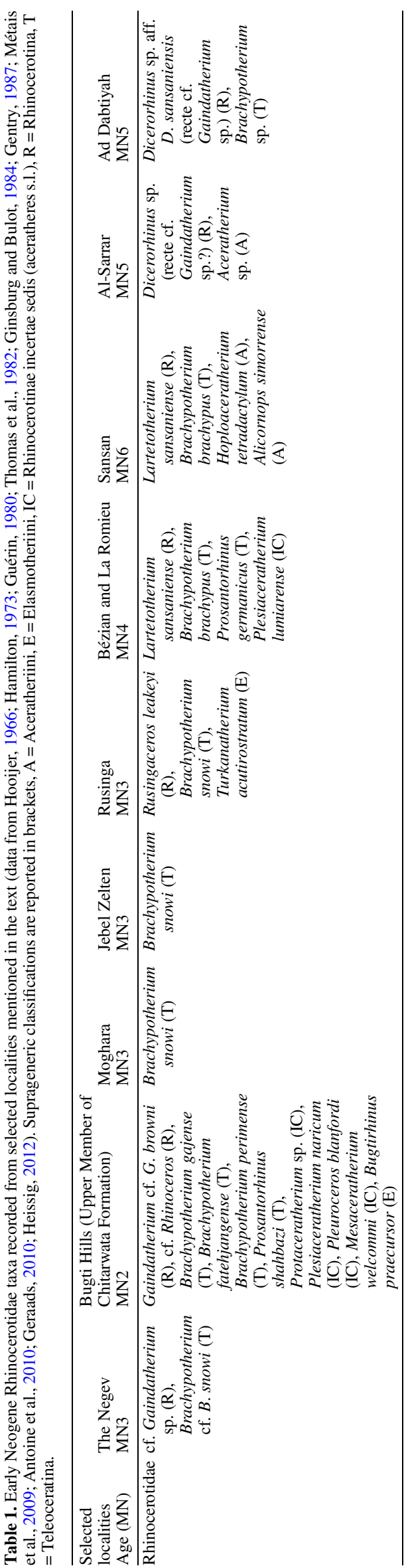

2010; Antoine and Becker, 2013; Lu et al., 2016; Fig. 6; Table 1). Nevertheless, early representatives of the subtribe Rhinocerotina (extant species and closely related fossil species) remain scarce compared to genera and species belonging to other rhinocerotid subtribes (Table 1). Consequently, the origin and geographic distribution of this group are still poorly understood. Within this framework, the record of the Negev is particularly important in depicting the dispersal routes of early Neogene Rhinocerotina and the origin and relationships of some taxa. Although the studied specimens consist only of a partial juvenile mandible and incomplete postcranial elements, some morphological and morphometric features allow us to exclude an attribution to aceratheriine and elasmotheiine species commonly documented in Asia (Table 1). Among the early Miocene true rhinoceroses, Rhinocerotina, some specimens from the Negev closely resemble Lartetotherium from Western Eurasia and Gaindatherium from the Siwalik Group. A few morphological characters, such as the shape of the oleocranon fossa in the humerus and of the distal articular surface of $\mathrm{mt} \mathrm{III,} \mathrm{lead} \mathrm{us}$ to assign the studied material to cf. Gaindatherium sp.

Two representatives of Gaindatherium occurred during the Miocene in the Siwaliks (Antoine, in press). The early representative, Gaindatherium browni, is documented from the early to late Miocene, ranging from 16.5-8.7 Ma (Antoine, in press and references therein), while its sister species, $G$. vidali Heissig, 1972, spans from 14.1-8 Ma. The two species exhibit considerable morphological and morphometric overlap (Antoine, in press), and several remains from the Siwalik area have been assigned only on a generic level. Recently, Gaindatherium sp. has been recorded from the Upper Member of the Chitarwata Formation (Pakistan) and assigned to the early Miocene (MN2) ca. 21 Ma (Métais et al., 2009; Antoine et al., 2010, 2013).

Gaindatherium and Lartetotherium are closely related, according to several cladistic analyses (Cerdeño, 1995; Antoine et al., 2003, 2010; Pandolfi, 2015; Lu et al., 2016), but the morphological differences between them probably justify generic separation (Heissig, 2012). The possibility of Lartetotherium and Gaindatherium evolving from the same common ancestor cannot be ruled out (Becker and Tissier, 2020), and the Negev record could provide evidence in support of this hypothesis. Gaindatherium reached the Levantine region during the late early Miocene (MN3) and subsequently may have given rise to a lineage leading to Lartetotherium in Europe (from MN4; Ginsburg and Bulot, 1984; Cerdeño, 1992; Antoine et al., 2000; Heissig, 2012; Becker and Tissier, 2020).

Some similarities in the morphology and size of humerus, ulna, and tibia (see comparisons) highlight the resemblance between the specimens from the Negev and the small rhinocerotine from the lower middle Miocene (MN5) Dam Formation at Ad Dabtiyah (Saudi Arabia), here assigned to cf. Gaindatherium sp. However, Gentry (1987) identified the Ad Dabtiyah rhinocerotine as ?Dicerorhinus sp. aff. sansaniensis, suggesting that it is closely related to the Sansan rhinoceros, previously considered to be Dicerorhinus sansaniensis. Although the specimens from Ad Dabtiyah need to be carefully revised, several morphological characters suggest a close affinity with $L$. sansaniense, as discussed by Gentry (1987, p. 425-427), or with Gaindatherium (as shown in the comparison section). This is true even if some 
other features, in particular of the upper teeth (e.g., lack of metacone folds on the premolars), prevent a reliable attribution to the Sansan species. The scanty tooth remains (incomplete right P4 and a small size upper incisor) from Al-Sarrar (Saudi Arabia), identified as Dicerorhinus sp. (Thomas et al., 1982), most probably also should be assigned to the taxon documented at $\mathrm{Ad}$ Dabtiyah. If the fossils from Ad-Dabtiah and Al-Sarrar belong to Gaindatherium, as here suggested, then the genus arrived via the Levantine corridor and continued in the Arabian region at least to the early middle Miocene (MN5).

The CT scan of the partial juvenile mandible (Supplementary Data 2,3) allows key morphological features of a teleoceratine to be viewed for the first time in the Negev. The morphology of p2 and $\mathrm{p} 3$ more closely resembles that of the large-sized B. snowi than that of other species of the same genus and could provide insight into the dispersal pattern of this taxon. Brachypotherium occurs within the Siwalik faunal sequence, from ca. $18 \mathrm{Ma}$ to ca. $7.2 \mathrm{Ma}$, with two relatively large-sized species, $B$. fatehjangense and $B$. perimense (Antoine, in press). The earliest representatives of this genus in Africa are B. snowi, described at Moghara (17.5 Ma; Egypt) and well documented at Jebel Zelten (ca. 16.5 Ma; Libya) and in other East African localities (Geraads, 2010), and B. minor from Buluk (ca. $17 \mathrm{Ma}$; Geraads and Miller, 2013). However, remains assigned to this genus from some localities dated back to ca. 20-18 Ma, such as Napak-Iriri (Uganda), should be classified with caution due to scarce and poorly preserved specimens (e.g., a worn and fragmented upper premolar and a very worn lower tooth; Hooijer, 1966, pl. 8, figs. 1, 2). In Europe, the genus is a little bit younger stratigraphically, documented by $B$. brachypus only after the beginning of MN4 (in Garonne Basin, at Bézian and La Romieu, together with L. sansaniense: Ginsburg and Bulot, 1984; Antoine et al., 2000; Heissig, 2012; Becker and Tissier, 2020). The morphological affinity of the remains from the Negev with $B$. snowi suggests dispersal of this species from the Levantine region towards Africa during the early Miocene. The origin of this taxon could be in southern Asia, and the description of new material from the Lower Siwaliks on the Potwar Plateau and coeval deposits in adjacent areas (e.g., belonging to B. fatehjangense) could be helpful to investigate the relationships between Eurasian and African brachypotheres.

\section{Conclusions}

The early Miocene sites of Oron and Anthracothere Hill in the Negev of Israel preserve at least two different rhinocerotid species: Brachypotherium cf. B. snowi and cf. Gaindatherium sp.

Brachypotherium cf. $B$. snowi from Israel is the first record of a teleoceratine in early Miocene sites in the Levant and demonstrates that the Levantine corridor was utilized by Brachypotherium as the genus dispersed presumably from Asia to Africa. Previously, cf. Gaindatherium sp. was only known from the Siwaliks of South East Asia. The material from the Negev demonstrates that this genus dispersed out of that region into the Levant and likely into Arabia. Furthermore, a phylogenetic relationship between Gaindatherium browni and the younger Lartetotherium sansaniense from Europe was previously hypothesized, suggesting they evolved from a common ancestor. The finds from the Negev may have given rise to a lineage leading to Lartetotherium in Europe.

Regardless of which exact evolutionary scenario bears out, the fossils from the Negev demonstrate the importance of the Negev and Arabia as a dispersal route.

\section{Acknowledgments}

This research is an outcome of a Synthesys Grant to L.P. (IL-TAF-1324). We are grateful for the following funding: Israel Foundation of Science grant 925/16 (R.R. and R.C.). A.G. is supported by a grant from Midwestern University. This paper has also been developed within the "Ecomorphology of fossil and extant Hippopotamids and Rhinocerotids" research project, funded by a grant to L.P. from the University of Florence ("Progetto Giovani Ricercatori Protagonisti" initiative). L.P. also thanks the European Commission's Research Infrastructure Action, EU-SYNTHESYS project AT-TAF-2550, DE-TAF3049, GB-TAF-2825, HU-TAF-3593, HU-TAF-5477, ES-TAF2997; part of this research received support from the SYNTHESYS Project (http://www.synthesys.info/), which is financed by European Community Research Infrastructure Action under the FP7 "Capacities" Program. We wish to thank G. Beiner for preparing the material and E. Lachman for the editing. The faunal collection is deposited at the National Natural History Collection of the Hebrew University of Jerusalem. The CT scanning was done at the Afeka Academic College of Engineering, Tel-Aviv, ACMPE laboratories, Micro-CT industrial. We thank P.-O. Antoine and M. Mihlbachler for their suggestions on a previous version of the manuscript. The data for Gaindatherium sp. from the Siwaliks of Potwar Plateau have been provided by P.-O. Antoine. We thank J. Tissier, E. Tsoukala, and P.-O. Antoine for their advice and comments, which improved this manuscript.

\section{Data availability statement}

Supplementary Data related with the manuscript are available from the Dryad Digital Repository: https://doi.org/10.5061/ dryad.mpg4f4r0b.

\section{References}

Antoine, P.-O., 1997, Aegyrcitherium beonensis, nouvel élasmothère (Mammalia, Perissodactyla) du gisement Miocène (MN4b) de Montréal-du-Gers (Gers, France). Position phylogénétique au sein des Elasmotheriini: Neues Jahrbuch für Geologie und Paläontologie Abhandlungen, v. 204, p. 399-414.

Antoine, P.-O., 2002, Phylogénie et évolution des Elasmotheriina (Mammalia, Rhinocerotidae): Mémoires du Muséum national d'histoire naturelle, Paris, v. 188 , p. $1-359$.

Antoine, P.-O., in press, Rhinocerotids from the Siwalik faunal sequence, in Badgley, C., Pilbeam, D., and Morgan, M., eds., At the Foot of the Himalayas: Paleontology and Ecosystem Dynamics of the Siwalik Record of Pakistan: Baltimore, The Johns Hopkins University Press.

Antoine, P.-O., and Becker, D., 2013, A brief review of Agenian rhinocerotids in Western Europe: Swiss Journal of Geosciences, v. 106, p. 135-146.

Antoine, P.O., and Welcomme, J.-L., 2000, A new rhinoceros from the lower Miocene of the Bugti Hills, Baluchistan, Pakistan: the earliest elasmotheriine: Palaeontology, v. 43, p. 795-816.

Antoine, P.-O., Bulot, C., and Ginsburg, L., 2000, Les rhinocérotidés (Mammalia, Perissodactyla) de l'Orléanien (Miocène inférieur) des bassins de la Garonne et de la Loire: intérêt biostratigraphique: Comptes Rendus de l'Académie des Sciences, Sciences de la Terre et des Planètes, v. 330, p. 571-576.

Antoine, P.-O., Duranthon, F., and Welcomme, J.L., 2003, Alicornops (Mammalia, Rhinocerotidae) dans le Miocène supérieur des collines Bugti 
(Balouchistan, Pakistan): implications phylogénétiques: Geodiversitas, v. 25 , p. $575-603$.

Antoine, P.-O., Downing, K.F., Crochet, J.Y., Duranthon, F., Flynn, L.J., Marivaux, L., Métais, G., Rajpar, A.R., and Roohi, G., 2010, A revision of Aceratherium blanfordi Lydekker, 1884 (Mammalia: Rhinocerotidae) from the early Miocene of Pakistan: postcranials as a key: Zoological Journal of the Linnean Society, v. 160, p. 139-194.

Antoine, P.-O., Métais, G., Orliac, M., Crochet, J.-Y., Flynn, L.J., Marivaux, L., Rajpar, A.R., Roohi, G., and Welcomme, J.-L., 2013, Mammalian Neogene biostratigraphy of the Sulaiman Province, Pakistan, in Flynn, L.J., Wang, X., and Fortelius, M., eds., Fossil Mammals of Asia: Neogene Biostratigraphy and Chronology: New York, Columbia University Press, p. 400-422.

Antoine, P.-O., Reyes, M.C., Amano, N., Claude, J., Bautista, A.P., Vos, J. de, and Ingicco, T., 2021, A new clade of rhinoceroses from the Pleistocene of Southeast Asia sheds light on mainland mammal dispersals to the Philippines: Zoological Journal of the Linnean Society, 2021, zlab009. https:// doi.org/10.1093/zoolinnean/zlab009.

Bar, O., and Zilberman, E., 2016, Subsidence and conversion of the Dead Sea basin to an inland erosion base level in the early middle Miocene as inferred from geomorphological analysis of its ancient western fluvial outlet: Geomorphology, v. 261, p. 147-161.

Becker, D., and Tissier, J., 2020, Rhinocerotidae from the early middle Miocene locality Gračanica (Bugojno Basin, Bosnia-Herzegovina): Palaeobiodiversity and Palaeoenvironments, v. 100, p. 395-412.

Březina, J., Luján, À.H., and Ivanov, M., 2017, Middle Miocene Mammals from the Czujan's sandpit (Mikulov, Czech Republic): Fifteenth Annua Meeting of the European Association of Vertebrate Palaeontologists, Munich, Germany, Technical Program and Abstracts, p. 25.

Calvo, R., and Bartov, Y., 2001, Hazeva Group, southern Israel: new observations, and their implications for its stratigraphy, paleogeography, and tectono-sedimentary regime: Israel Journal of Earth Sciences, v. 50, p. 71-99.

Cerdeño, E., 1986, El esqueleto postcraneal de Lartetotherium sansaniense (Mammalia, Rhinocerotadiae): Estudios Geologicos, v. 42, p. 197-209.

Cerdeño, E., 1992, Spanish Neogene rhinoceroses: Palaeontology, v. 35, p. $297-308$

Cerdeño, E., 1993, Étude sur Diaceratherium aurelianense et Brachypotherium brachypus (Rhinocerotidae, Mammalia) du Miocène moyen de France: Bulletin du Muséum national d'histoire naturelle, Paris, v. 15, p. 25-77.

Cerdeño, E., 1995, Cladistic analysis of the family Rhinocerotidae (Perissodactyla): American Museum Novitates, v. 3143, p. 1-25.

Cerdeño, E., 1996a, Lartetotherium (Rhinocerotidae) en la fauna con Hispanotherium del Mioceno Medio de la Retama, Cuenca, España: Revista Española de Paleontología, v. 11, p. 193-197.

Cerdeño, E., 1996b, Prosantorhinus, the small teleoceratine rhinocerotid from the Miocene of Western Europe: Geobios, v. 29, p. 111-124.

Cerdeño, E., and Nieto, M., 1995, Changes in Western European Rhinocerotidae related to climatic variations: Palaeogeography Palaeoclimatology Palaeoecology, v. 114, p. 325-338.

Colbert, E.H., 1934, A new rhinoceros from the Siwalik Beds of India: American Museum Novitates, v. 749, p. 1-13.

Crusafont, M., Villalta, J. F., and Truyols, J., 1955, El Burdigaliense continental de la Cuenca del Vallés-Penedés: Memorias y Comunicaciones del Instituto Geológico, Barcelona, v. 12, p. 1-272.

Cuvier, G., 1822, Recherches sur les Ossemens Fossiles de Quadrupèdes (2nd ed.): Paris, Edmond d'Ocagne, v. 5, 431 p.

Deraniyagala, P.E.P., 1951, A hornless rhinoceros from the Mio-Pliocene deposits of East Africa: Spolia Zeylanica, v. 26, p. 133-135.

Falconer, H., and Cautley, P.T., 1846, Fauna Antiqua Sivalensis, being the fossil zoology of the Sewalik Hills, in the North of India Illustrations, part VIII: Suidae and Rhinocerotidae: London, Smith, Elder and Co, pls. 69-80.

Fourtau, R., 1920, Contribution à l'Étude des Vertébrés Miocènes de l'Egypte: Cairo, Government Press, $121 \mathrm{p}$.

Gentry, A.W., 1987, Rhinoceroses from the Miocene of Saudia Arabia, in Whybrow, P.J., ed., Miocene Geology and Palaeontology of Ad Dabtiyah, Saudi Arabia: London, Bulletin of the British Museum of Natural History (Geology), v. 41, p. 409-432.

Gentry, A., Rössner, G.E., and Heizmann, E.P.J., 1999, Suborder Ruminantia, in Rössner, G. E., and Heissig, K., eds., The Miocene Land Mammals of Europe: Munich, Verlag Dr. Friedrich Pfeil, p. 225-258.

Geraads, D., 2010, Rhinocerotidae, in Werdelin, L., and Sanders, W.J., eds., Cenozoic Mammals of Africa: Berkeley, University of California Press, p. 669-683.

Geraads, D., and Miller, E., 2013, Brachypotherium minor n. sp., and other Rhinocerotidae from the early Miocene of Buluk, Northern Kenya: Geodiversitas, v. 35 , p. $359-375$.

Geraads, D., McCrossin, M., and Benefit, B., 2012, A new rhinoceros, Victoriaceros kenyensis gen. et sp. nov., and other Perissodactyla from the middle
Miocene of Maboko, Kenya: Journal of Mammalian Evolution, v. 19, p. $57-75$.

Geraads, D., Lehmann, T., Peppe, D.J., and McNulty, K.P., 2016, New Rhinocerotidae from the Kisingiri localities (lower Miocene of Western Kenya) Journal of Vertebrate Paleontology, v. 36, 3. https://doi.org/10.1080/ 02724634.2016.1103247.

Ginsburg, L., and Bulot, C., 1984, Les Rhinocerotidae (Perissodactyla, Mammalia) du Miocène de Bézian à La Romieu (Gers): Bulletin du Muséum national d'histoire naturelle de Paris, v. 6, p. 353-377.

Goldsmith, N., Tchernov, E., Ginsburg, L., Tassy, P., and Van Couvering, J.A. 1982. Ctenodactylid rodents in the Miocene Negev Fauna of Israel: Nature, v. 296 , p. $645-647$.

Goldsmith, N., Hirsch, F., Friedman, G., Tchernov, E., Derin, B., Gerry, E., Horowits, A., and Weinberger, G., 1988, Rotem mammals and Yeroham crassostreids: stratigraphy of the Hazeva Formation (Israel) and the paleogeography of Miocene Africa: Newsletter on Stratigraphy, v. 20, p. 73-90.

Gray, J.E., 1821, On the natural arrangement of vertebrose animals: London Medical Repository, vol. 15, p. 296-310.

Gray, J.E., 1825, A synopsis of the genera of reptiles and amphibia, with a description of some new species: Annals of Philosophy, n.s., v. 10, p. 193-217.

Grossman, A., Liutkus-Pierce, C., Kyongo, B., and M'Kirera, F., 2014, New fauna from Loperot contributes to the understanding of Early Miocene catarrhine communities: International Journal of Primatology, v. 35, p. 1253-1274.

Grossman, A., Calvo, R., López-Antoñanzas, R., Knoll, F., Hartman, G., and Rabinovich, R., 2019, First record of Sivameryx (Cetartiodactyla, Anthracotheriidae) from the lower Miocene of Israel highlights the importance of the Levantine Corridor as a dispersal route between Eurasia and Africa: Journal of Vertebrate Paleontology, v. 39, 2. https://doi.org/10.1080/ 02724634.2019.1599901

Guérin, C., 1980, Les rhinocéros (Mammalia, Perissodactyla) du Miocene terminal au Pléistocène supérieur en Europe occidentale, comparaison avec les espèces actuelles: Documents des Laboratoires de Géologie de la Facultè des Sciences de Lyon, v. 79, p. 3-1183.

Guérin, C., 2000, The Neogene rhinoceroses of Namibia: Palaeontologia Africana, v. 36, p. 119-138.

Guérin, C., 2003, Miocene Rhinocerotidae of the Orange River Valley, Namibia: Memoir of the Geological Survey of Namibia, v. 19, p. 257-281.

Guérin, C., and Pickford, M., 2003, Ougandatherium napakense nov. gen. nov. sp., le plus ancien Rhinocerotidae Iranotheriinae d'Afrique: Annales de Paléontologie, v. 89, p. 1-35.

Gvirtzman, G., and Buchbinder, B., 1969, Outcrops of Neogene Formation in the central and southern coastal plain, Hashephela and Beer Sheva' Regions, Israel: Geological Survey of Israel Bulletin, v. 50, p. 1-73.

Hall, J.K., 1997, Landforms of Israel and adjacent areas: Jerusalem, Geological Survey of Israel, 1:500000 scale, 1 sheet.

Hamilton, W.R., 1973, North African Lower Miocene rhinoceroses: Bulletin of the British Museum (Natural History), Geology, v. 24, p. 349-395.

Hamilton, W.R., Whybrow, P., and McClure, H., 1978, Fauna of fossil mammals from the Miocene of Saudi Arabia: Nature, v. 274, p. 248-249.

Hay, O.P., 1902, Bibliography and catalogue of the fossil Vertebrata of North America: Bulletin of the United States Geological Survey, v. 179, p. 1-868.

Heissig, K., 1972, Paläontologische und geologische Untersuchungen im Tertia von Pakistan. 5. Rhinocerotidae aus den unteren und mittleren Siwalik-Schichten: Abhandlungen der Bayerischen Akademie Wissenschaften, Mathematisch-Naturwissenschaftliche Klasse, v. 152, p. 1-112.

Heissig, K., 1974, Neue Elasmotherini (Rhinocerotidae, Mammalia) aus dem Obermiozän Anatoliens: Mitteilungen der Bayerische Staatsammlung für Paläontologie und historische Geologie, v. 14, p. 21-35.

Heissig, K., 1976, Rhinocerotidae (Mammalia) aus der Anchitherium-Fauna Anatoliens: Geologisches Jahrbuch B, v. 19, p. 3-121.

Heissig, K., 2012, Les Rhinocerotidae (Perissodactyla) de Sansan, in Peigné, S., and Sen, S., eds., Mammifères de Sansan: Paris, Mémoires du Muséum national d'histoire naturelle, v. 203, p. 317-485.

Hooijer, D.A., 1966, Fossil mammals of Africa no. 21. Miocene rhinoceroses of East Africa: Bulletin of the British Museum (Natural History), Geology, v. 13, p. 119-190.

Hooijer, D.A., 1971, A new rhinoceros from the late Miocene of Loperot, Turkana district, Kenya: Bulletin of the Museum of Comparative Zoology, Harvard University, v. 142, p. 339-392.

Koufos, G.D., Zouros, N., and Mourouzidou, O., 2003, Prodeinotherium bavaricum (Proboscidea, Mammalia) from Lesvos Island, Greece; the appearance of deinotheres in the Eastern Mediterranean: Geobios, v. 36 p. 305-315.

Lartet, E., 1837, Note sur les ossements fossiles des terrains tertiaires de Simorre, de Sansan etc., dans le département du Gers, et sur la découverte récente d'une mâchoire de singe fossile: Comptes Rendus de l'Académie des Sciences, Paris, v. 4, p. 85-93. 
Lartet, E., 1851, Notice sur la Colline de Sansan, suivie d'une récapitulation des diverses espèces d'animaux vertébrés fossiles trouvés soit à Sansan, soit dans d'autres gisements du terrain Miocène dans le bassin sous-Pyrénéen: Auch, J.A. Portes, 45 p.

López-Antoñanzas, R., Gutkin, V., Rabinovich, R., Calvo, R., and Grossman, A., 2016, A transitional gundi (Rodentia: Ctenodactylidae) from the Miocene of Israel: PLoS ONE, v. 11, p. e0151804. https://doi.org/10. 1371/journal.pone.0151804.

Lu, X., Zheng, X., Sullivan, C., and Tan, J., 2016, A skull of Plesiaceratherium gracile (Rhinocerotidae, Perissodactyla) from a new lower Miocene locality in Shandong Province, China, and the phylogenetic position of Plesiaceratherium: Journal of Vertebrate Paleontology, v. 36, 3. https://doi.org/10. 1080/02724634.2016.1095201.

Margaritz, M., 1972, The paleoenvironment of the Yeruham oyster beds, Miocene, Israel as deduced from carbon isotopic composition: Israel Journal of Earth Sciences, v. 21, p. 179-185.

Métais, G., Antoine, P.-O., Baqri, S.R.H., Marivaux, L., and Welcomme, J.L., 2009, Lithofacies, depositional environments, regional biostratigraphy, and age of the Chitarwata Formation in the Bugti Hills, Balochistan, Pakistan: Journal of Asian Earth Sciences, v. 34, p. 154-167.

Neev, D., 1960, A pre-Neogene erosion channel in the southern coastal region of Israel: Bulletin of the Geological Survey of Israel, v. 25, p. 1-21.

Nouel, E., 1866, Mémoire sur un nouveau rhinocéros fossile: Mémoires de la Société d'Agriculture, Sciences, Belle-Lettres et Art d'Orléans, v. 8, p. 241-251.

Osborn, H.F., 1900, Phylogeny of the rhinoceroses of Europe: Memoirs of the American Museum of Natural History, v. 13, p. 229-267.

Owen, R., 1848, The Archetype and Homologies of the Vertebrate Skeleton: London, John van Voorst, 203 p.

Pandolfi, L., 2015, Persiatherium rodleri, gen. et sp. nov. (Mammalia, Rhinocerotidae) from the upper Miocene of Maragheh (northwestern Iran): Journal of Vertebrate Paleontology, v. 36, 1. https://doi.org/10.1080/02724634. 2015.1040118.

Pilgrim, G.E., 1910, Notices of new mammalian genera and species from the Tertiaries of India: Records of the Geological Survey of India, v. 40, p. 63-71.

Popov, S.V., Rögl, F., Rozanov, A.Y., Steininger, F.F., Shcherba, I.G., and Kovac, M., 2004, Lithological-paleogeographic maps of Paratethys. 10 Maps. Late Eocene to Pliocene: Courier Forschungsinstitut Senckenberg, v. 250 , p. $1-46$

Prieto, J., Antoine, P.-O., Made, J. van der, Metais, G., Laq The Phuc, Quy Trurong Quan, Schneider, S., Dang Ngoc Tran, Vasilyan, D., Luong The Viet, and Boehme, M., 2018, Biochronological and palaeobiogeographical significance of the earliest Miocene mammal fauna from Northern Vietnam: Palaeobiology and Palaeoenvironment, v. 98, p. 287-313.
Roger, O., 1904, Wirbeltierreste aus dem Obermiocän der bayerisch-schwäbischen Hochebene. Part 5: Bericht des Naturwissenschaftlichen Vereins für Schwaben und Neuburg, v. 36, p. 1-21.

Santafé-Llopis, J.V., Casanovas-Cladellas, M.L., and Belinchon, M., 1987, Una nueva espece de Dicerorhinus, D. montesi (Rhinocerotoidea, Perissodactyla) del yacimiento de Buñol (Orleaniense medio) (Valencia, España): Paleontologia i Evolució, v. 21, p. 271-293.

Savage, R.J.G., and Tchernov, E., 1968, Miocene mammals of Israel: Proceedings of the Geological Society of London, v. 1648, p. 98-101.

Scherler, L., Mennecart, B., Hiard, F., and Becker, D., 2013, Evolutionary history of hoofed mammals during the Oligocene-Miocene transition in Western Europe: Swiss Journal of Geosciences, v. 106, p. 349-369.

Sen, S., 2013, Dispersal of African mammals in Eurasia during the Cenozoic: ways and whys: Geobios, v. 46, p. 159-72.

Short, R.A., Wallace, S.C., and Emmert L.G., 2019, A new species of Teleoceras (Mammalia, Rhinocerotidae) from the late Hemphillian of Tennessee: Bulletin of the Florida Museum of Natural History, v. 56, p. 183-260.

Sneh, A., Bartov, Y., and Rosensaft, M., 1998, Geological map of Israel: Jerusalem, Geological Survey of Israel, scale 1:200000, 4 sheets.

Tassy, P., 1990, The "Proboscidean Datum Event": how many proboscideans and how many events? in Lindsay, E.H., Fahlbusch, V., and Mein, P., eds, European Neogene Mammal Chronology, NATO ASI Series (Series A: Life Sciences): Boston, Springer, p. 237-252.

Tchernov, E., Ginsburg, L., Tassy, P., and Goldsmith, N.F., 1987, Miocene mammals of the Negev (Israel): Journal of Vertebrate Paleontology, v. 7, p. 284-310.

Thomas, H., Sen, S., Khan, M., Battail, B., and Ligabue, G., 1982, The lower Miocene fauna of As-Sarrar (Eastern Province, Saudi Arabia): Atlal, v. 5, p. 109-136.

van der Made, J., 1999, Intercontinental relationship Europe-Africa, in Rössner, G.E., and Heissig, K., eds., The Miocene Land Mammals of Europe: Munich, Verlag Dr. Friedrich Pfeil, p. 457-472.

van der Made, J., 2010, The rhinos from the middle Pleistocene of Neumark Nord (Saxony-Anhalt): Veröffentlichungen des Landesamtes für Denkmalpflege und Archäologie, v. 62, p. 432-527.

Zilberman, E., and Calvo, R., 2013, Remnants of Miocene fluvial sediments in the Negev Desert, Israel, and the Jordanian Plateau: evidence for an extensive subsiding basin in the northwestern margins of the Arabian plate: Journal of African Earth Sciences, v. 82, p. 33-53.

Accepted: 24 June 2021 